\title{
Perancangan Struktur Bangunan Central Sterile Supply Department (CSSD) Rumah Sakit Mawaddah Medika Mojokerto \\ (Design of Central Sterile Supply Department (CSSD) Building Structure Mawaddah Medika Hospital Mojokerto)
}

\author{
Galih Damar Pandulu ${ }^{1 *}$, Mukhlis Pribadi ${ }^{2}$, Handika Setya Wijaya ${ }^{3}$, Diana Ningrum ${ }^{4}$ \\ ${ }^{1,3,4}$ Program Studi Teknik Sipil, Fakultas Teknik, Universitas Tribhuwana Tungga Dewi Malang \\ ${ }^{2}$ Universitas 17 Agustus 1945 Banyuwangi
}

\begin{tabular}{|c|c|}
\hline ARTICLE INFO & ABSTRAK \\
\hline $\begin{array}{l}\text { Article history } \\
\text { Received : } 15 \text { August } 2021 \\
\text { Revised : } 17 \text { November } 2021 \\
\text { Accepted : } 13 \text { December } 2021\end{array}$ & $\begin{array}{l}\text { Rumah Sakit Mawaddah Medika, membutuhkan kompetensi personil } \\
\text { yang mempunyai keahlian Bangunan Gedung, serta membutuhkan } \\
\text { peralatan yang mendukung dalam hal survei maupun peralatan analisa } \\
\text { untuk menghitung struktur bangunan gedung yang memenuhi standar. }\end{array}$ \\
\hline $\begin{array}{l}\text { DOI : } \\
\text { https://doi.org/10.33366/jast.v5 } \\
\text { i2.2676 }\end{array}$ & $\begin{array}{l}\text { Tujuan dari kegiatan pengabdian kepada masyarakat ini adalah penerapan } \\
\text { aplikasi teknologi Structural Analysis And Design (STAAD) Pro V8i untuk } \\
\text { perhitungan struktur bangunan gedung yang aman yang harus disediakan } \\
\text { oleh rumah sakit untuk menunjang aktivitasnya. Hasil perhitungan }\end{array}$ \\
\hline $\begin{array}{l}\text { Keywords : } \\
\text { infrastructure; supervision; } \\
\text { quality }\end{array}$ & $\begin{array}{l}\text { menentukan dimensi beton dan tulangannya berdasarkan momen aksial dan } \\
\text { gaya yang dipikul pada gedung Central Steril Supply Department. Metode } \\
\text { perhitungan struktural dengan Structural Analysis And Design (STAAD) }\end{array}$ \\
\hline $\begin{array}{l}\text { *e-mail corresponding author:: } \\
\text { galih.damar@ unitri.ac.id }\end{array}$ & $\begin{array}{l}\text { Pro V8i. Hasil dari kegiatan pengabdian masyarakat ini, mitra memperoleh } \\
\text { pendampingan perencanaan struktur bangunan gedung sehingga diperoleh } \\
\text { implementasi perencanaan yang efektif dan efisien }\end{array}$ \\
\hline
\end{tabular}

PENERBIT

\section{UNITRI PRESS}

Jl. Telagawarna, TlogomasMalang, 65144, Telp/Fax: $0341-565500$

This is an open access article under the Creative Commons Attribution-ShareAlike $\quad \mathbf{4 . 0}$ International License. Any further distribution of this work must maintain attribution to the author(s) and the title of the work, journal citation and DOI. CC-BY-SA

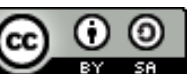

\begin{abstract}
Mawaddah Medika Hospital requires personnel who have building expertise and require supporting equipment in terms of supervision and analysis to calculate building structures that meet standards. The purpose of this community service is the application of the Structural Analysis And Design (STAAD) Pro V8i application to calculate safe building structures that hospitals must provide to support their activities. The results of calculating the dimensions of the concrete and its reinforcement are based on the axial moments and forces carried on the Central Steril Supply Department building. Structural calculation method with Structural Analysis And Design (STAAD) Pro V8i. As a result of this community service activity, partners receive assistance in planning the structure of the building so that an effective planning implementation can be obtained.
\end{abstract}




\section{PENDAHULUAN}

Kebutuhan fasilitas kesehatan pada Kabupaten Mojokerto, salah satunya dipenuhi dengan keberadaan Rumah Sakit Mawaddah Medika. Untuk memenuhi kebutuhan masyarakat akan fasilitas kesehatan maka Rumah Sakit Mawaddah Medika melakukan peningkatan fasilitas berupa pembangunan gedung Central Steril Supply Department (CSSD). Dalam struktur organisasi di Rumah Sakit Mawaddah Medika, membutuhkan kompetensi personil yang mempunyai keahlian Bangunan Gedung, serta membutuhkan peralatan yang mendukung dalam hal survei maupun peralatan analisa untuk menghitung struktur bangunan gedung yang memenuhi standar.

Berdasarkan permasalahan mitra tersebut maka dilakukan pengabdian masyarakat karena Universitas Tribhuwana Tunggadewi memiliki kompetensi sumberdaya dengan keahlian bangunan gedung serta peralatan yang mendukung dalam survey dan analisis struktur bangunan gedung. Dengan keterlibatan dosen dalam kegiatan pengabdian masyarakat ini diharapkan terdapat penerapan aplikasi teknologi Structural Analysis And Design (STAAD) Pro V8i untuk perhitungan struktur bangunan gedung yang aman yang harus disediakan oleh rumah sakit untuk menunjang aktivitasnya. Efektif manajemen yang melibatkan multidisiplin dalam perencanaan, pendidikan, dan pemantauan seperti pengelola merencanakan ruangan, peralatan, dan sumber daya yang dibutuhkan yang aman dan efektif untuk menunjang pelayanan klinis [1]. Diperlukan dukungan manajemen untuk peningkatan fasilitas kesehatan untuk meningkatkan kualitas layanan [2]. Rumah Sakit Mawaddah Medika merupakan rumah sakit kelas D yang berlokasi di Jalan Raya Ngijingan RT 001 RW 001, Desa Purwojati Kecamatan Ngoro, Kabupaten Mojokerto yang terus berupaya untuk meningkatkan prasarana salah satunya merencanakan pembangunan gedung 5 lantai yang termasuk di dalamnya terdapat Central Steril Supply Departement (CSSD). Luaran dari kegiatan pengabdian ini adalah tersediannya dokumen perencanaan berupa perhitungan struktur bangunan gedung yang aman serta memenuhi kaidah perencanaan standar perencanan struktur bangunan gedung.

Peningkatan dan penyediaan fasilitas kesehatan meningkat di dunia serta dihadapkan pada tantangan infrastruktur salah adalah ketahanan terhadap bencana [3]. Pemenuhan tuntutan dinamis dari pasien akan peningkatan layanan fasilitas kesehatan memerlukan salah satunya renovasi atau pembangunan gedung baru dalam rangka mempertahankan atau meningkatkan layanan rumah sakit [4]. Aplikasi software analisis dan desain struktur dalam perhitungan suatu struktur bangunan mempermudah dalam menganalisis gaya-gaya dalam dan efisiensi desain elemen-elemen struktur [5]. Perangkat lunak yang terutama digunakan untuk seluruh bagian perancangan dan analisis adalah STAAD [6]. Software Staadpro V8i digunakan dalam perancangan struktur beton bertulang 5 lantai untuk pengembangan ruang dan CSSD rumah sakit Mawaddah Medika di Kabupaten Mojokerto. 


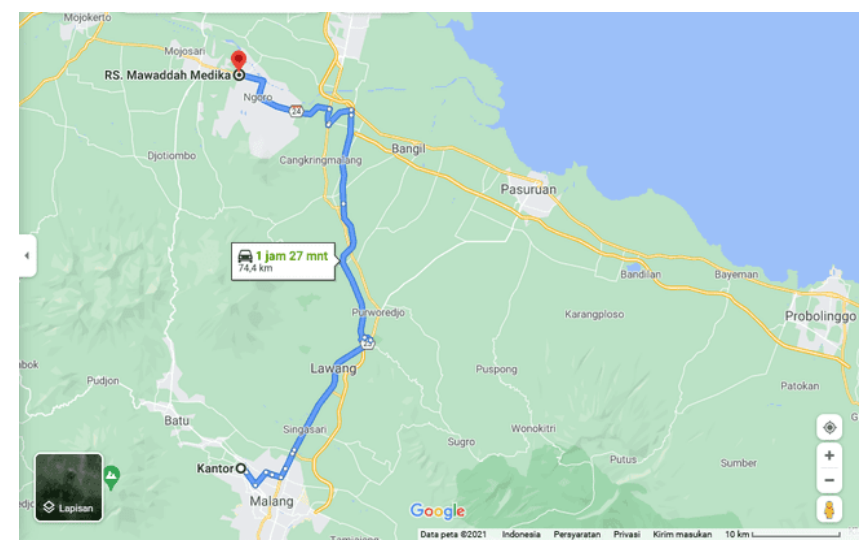

Gambar 1. Lokasi rumah sakit Mawaddah Medika

Software Staadpro V8i melakukan kombinasi pembebanan berupa kombinasi antara beban mati, beban hidup, dan beban gempa, sehingga memperoleh gaya maksimum untuk desain elemen struktur. Hasil Staadpro V8i ini adalah berupa gaya-gaya dalam (gaya momen, lintang, normal), serta deformasi struktur yang terjadi. Analisis struktur untuk menentukan reaksi, gaya-gaya dalam (Mx, My, Mz, Fx, Fy dan Fz) dan deformasi yang terjadi pada struktur akibat beban yang bekerja (gaya-gaya luar) [7]. Output digunakan untuk melakukan disain elemen-elemen struktur. Output dari analisis dan disain struktur adalah gambar detail struktur [8].

\section{METODE KEGIATAN}

Tahapan kegiatan ini adalah melakukan focus group discussion (FGD) dengan mitra yaitu pengelola rumah sakit serta masyarakat. Hasil dari FGD berupa kebutuhan pendampingan tenaga ahli tentang perencanan struktur bagunan gedung serta kebutuhan perencanaan yang efektif dan efisien. Sementara dari masyarakat juga menginginkan struktur bangunan rumahsakit yang kokoh sehingga aman jika terjadi gempa. Keinginan mitra diakomodir dengan melakukan survei lahan dan perhitungan struktur. Hasil Survei lapangan dan Perhitungan struktur dengan Struktural Analysis And Design (STAAD) Pro V8i merupakan tahapan dari metode penerapan ilmu pengetahuan dan teknologi (IPTEK).

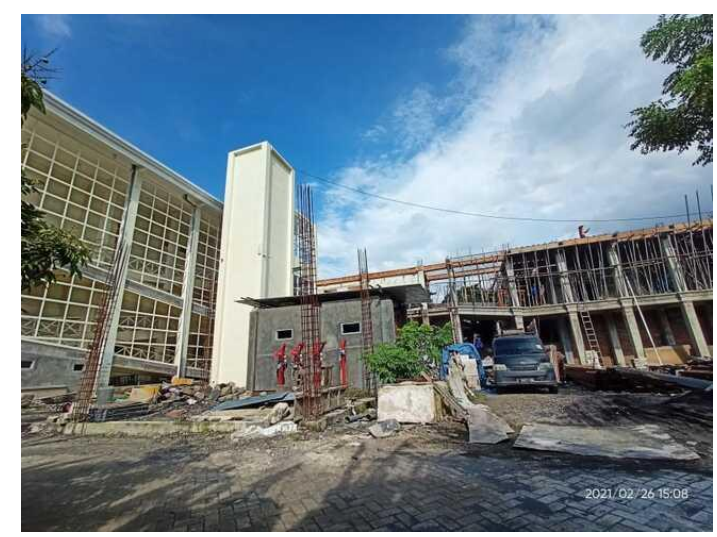

Gambar 2. Lahan pengembangan gedung CSSD 
Dalam perhitungan mengacu pada SNI 2847:2019 tentang persyaratan beton struktural untuk bangunan gedung [9]. SNI 1726:2019 tentang Tata cara perencanaan ketahanan gempa untuk struktur bangunan gedung dan non gedung [10] dan SNI 1727:2013 tentang Beban desain minimum dan kriteria terkait untuk bangunan gedung dan struktur lain [11] yaitu:

\section{a. Beban Mati}

Beban mati adalah bobot keseluruh bahan konstruksi yang terpasang, termasuk lantai, dinding, tangga, plafond, atap, dinding partisi tetap, finishing, klading gedung dan komponen arsitektural dan struktural lainnya serta peralatan untuk layanan yang terpasang serta berat derek dan sistem pengangkut material.

b. Beban Hidup

Berdasarkan SNI 1727:2013 beban hidup adalah beban yang diakibatkan oleh pengguna dan penghuni bangunan gedung atau struktur lain.

c. Beban Gempa

Pengaruh gempa berdasarkan analisa dinamik, dengan gaya-gaya di dalam struktur tersebut yang terjadi oleh tanah akibat gempa itu sendiri. berdasarkan analisa dinamik, beban gempa itu gaya-gaya di dalam struktur tersebut terjadi oleh tanah akibat gempa tersebut.

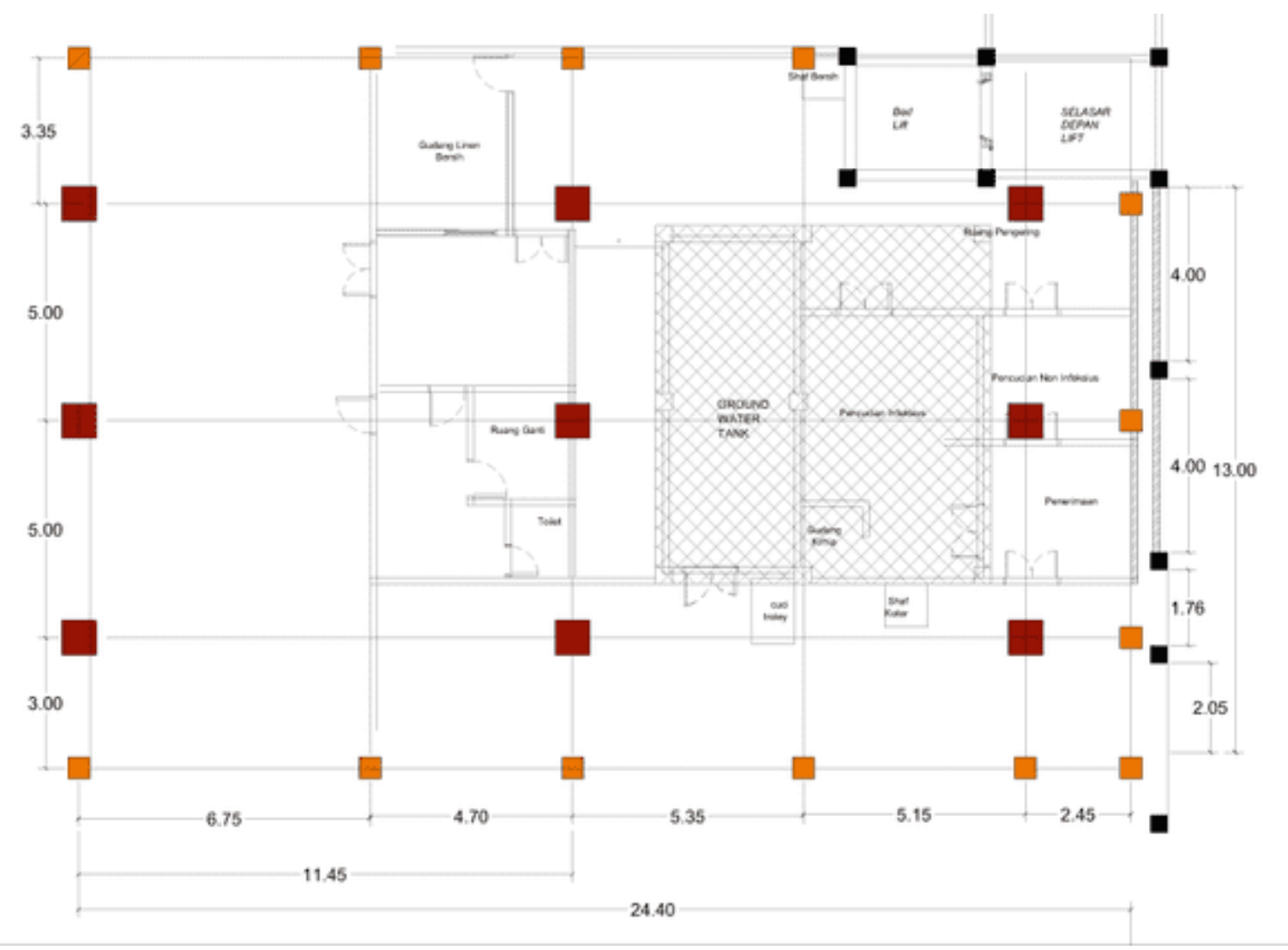

Gambar 3. Denah gedung CSSD 


\section{KARYA UTAMA}

Pengembangan gedung CSSD berada pada lahan pengembangan rumah sakit Mawaddah Medika. Dalam kegiatan pengabdian masyarakat berupa perhitungan struktur gedung CSSD 5 lantai melalui perhitungan pembebanan berupa beban mati meliputi berat sendiri balok, plafon dan penggantung sebesar $130 \mathrm{~kg} / \mathrm{m} 2$ serta dinding bata ringan sebesar $400 \mathrm{~km} / \mathrm{m}$, beban hidup meliputi beban penghuni sebesar 479 $\mathrm{kg} / \mathrm{m} 2$, beban air hujan sebesar $50 \mathrm{~kg} / \mathrm{m} 2$ serta beban gempa yang bekerja pada bangunan.



Gambar 4. Struktur portal gedung CSSD 5 Lantai

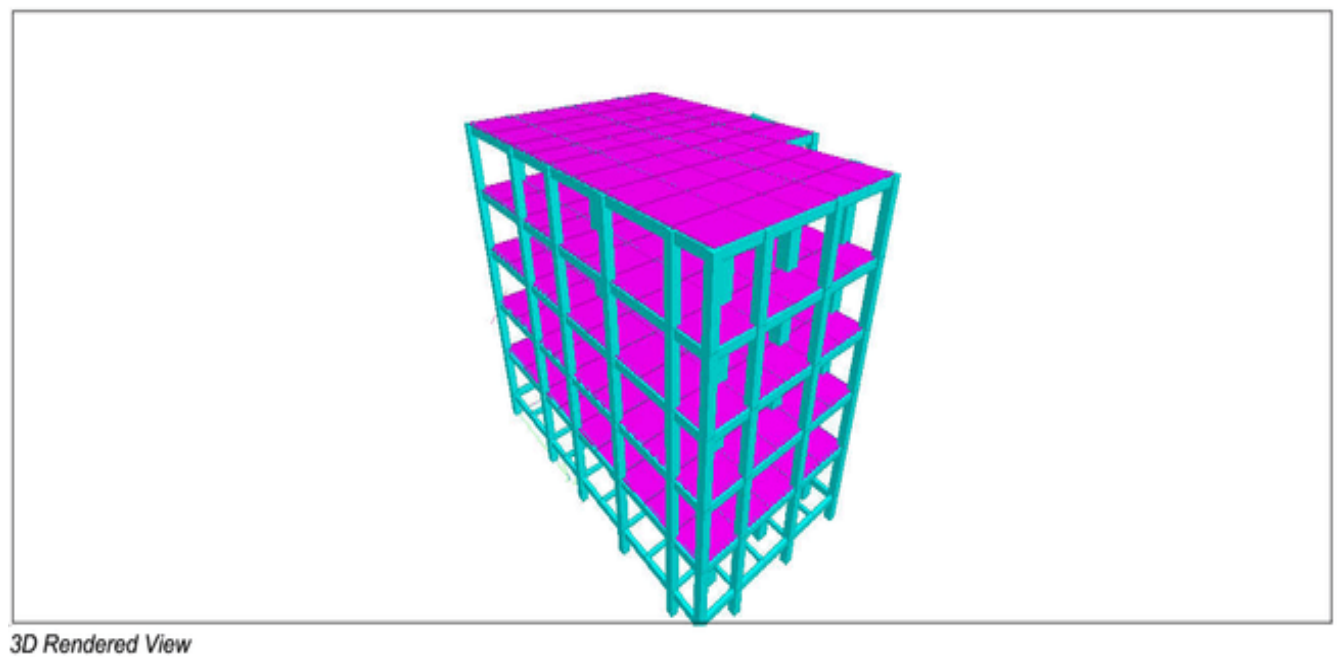

\section{Gambar 5. Tampak 3D portal gedung CSSD 5 Lantai}

Pengaruh gempa pada struktur ditentukan berdasarkan analisa dinamik, maka yang diartikan dalam beban gempa itu gaya gaya di dalam struktur tersebut yang terjadi oleh tanah akibat gempa itu sendiri. 


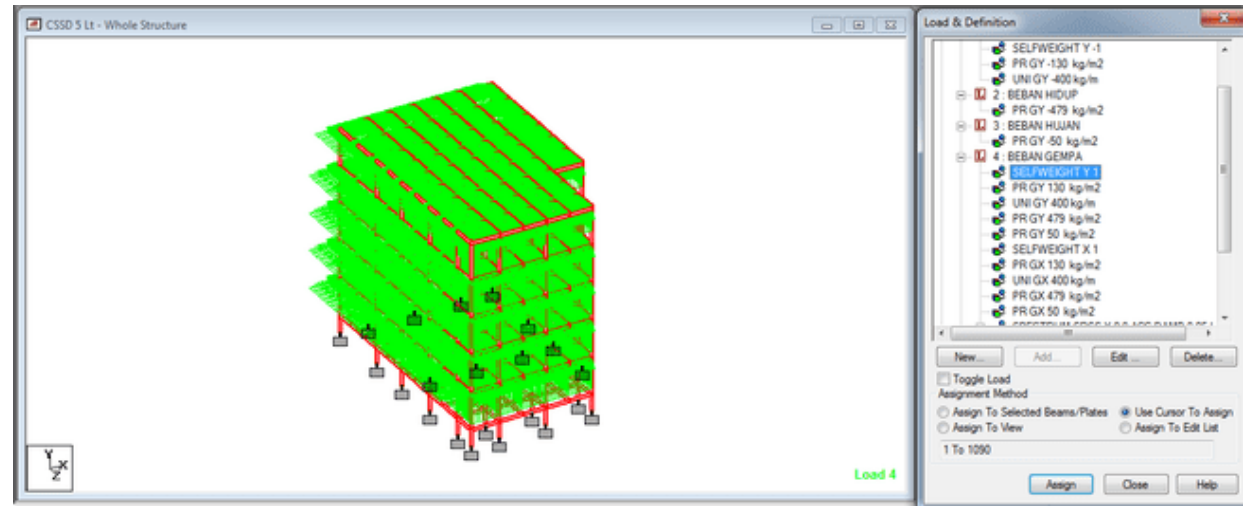

Gambar 6. Gambar dan input beban gempa portal gedung CSSD 5 Lantai

Hasil output analisis struktur dari Software Staadpro berupa gaya-gaya dalam maksimum (momen, Lintang, dan normal) serta deformasi struktur. Pada lantai 1 untuk sloof ukuran 40/70 didapat $\mathrm{Mu}^{+}=219,842 \mathrm{kNm}, \mathrm{Mu}^{-}=257,373 \mathrm{kNm}$ dan $\mathrm{Vu}=62,362$ $\mathrm{kN}$, sloof ukuran 20/40 didapat $\mathrm{Mu}^{+}=31,003 \mathrm{kNm}, \mathrm{Mu}^{-}=19,662 \mathrm{kNm}$ dan $\mathrm{Vu}=11,052$ $\mathrm{kN}$, balok ukuran dan sloof ukuran 20/30 didapat $\mathrm{Mu}^{+}=19,809 \mathrm{kNm}, \mathrm{Mu}^{-}=33,166 \mathrm{kNm}$ dan $\mathrm{Vu}=761,106 \mathrm{kN}$.

Pada lantai 2 untuk balok ukuran 45/90 didapat $\mathrm{Mu}^{+}=673,219 \mathrm{kNm}, \mathrm{Mu}^{-}=818,697$ $\mathrm{kNm}$ dan $\mathrm{Vu}=800,769 \mathrm{kN}$, balok ukuran $25 / 50$ didapat $\mathrm{Mu}^{+}=107,364 \mathrm{kNm}, \mathrm{Mu}^{-}=$ $89,534 \mathrm{kNm}$ dan $\mathrm{Vu}=102,10 \mathrm{kN}$, balok ukuran 20/40 didapat $\mathrm{Mu}^{+}=85,754 \mathrm{kNm}, \mathrm{Mu}^{-}=$ $76,510 \mathrm{kNm}$ dan $\mathrm{Vu}=61,698 \mathrm{kN}$ dan balok ukuran 20/30 didapat $\mathrm{Mu}^{+}=43,868 \mathrm{kNm}, \mathrm{Mu}^{-}$ $=21,768 \mathrm{kNm}$ dan $\mathrm{Vu}=127,028 \mathrm{kN}$.

Pada lantai 3 untuk balok ukuran 45/90 didapat $\mathrm{Mu}^{+}=774,113 \mathrm{kNm}, \mathrm{Mu}^{-}=797,319$ $\mathrm{kNm}$ dan $\mathrm{Vu}=746,431 \mathrm{kN}$, balok ukuran $25 / 50$ didapat $\mathrm{Mu}^{+}=115,564 \mathrm{kNm}, \mathrm{Mu}^{-}=$ $92,994 \mathrm{kNm}$ dan $\mathrm{Vu}=124,767 \mathrm{kN}$, balok ukuran 20/40 didapat $\mathrm{Mu}^{+}=84,424 \mathrm{kNm}, \mathrm{Mu}^{-}=$ $79,224 \mathrm{kNm}$ dan $\mathrm{Vu}=135,382 \mathrm{kN}$ dan balok ukuran $20 / 30$ didapat $\mathrm{Mu}^{+}=43,109 \mathrm{kNm}$, $\mathrm{Mu}^{-}=23,049 \mathrm{kNm}$ dan $\mathrm{Vu}=127,767 \mathrm{kN}$.

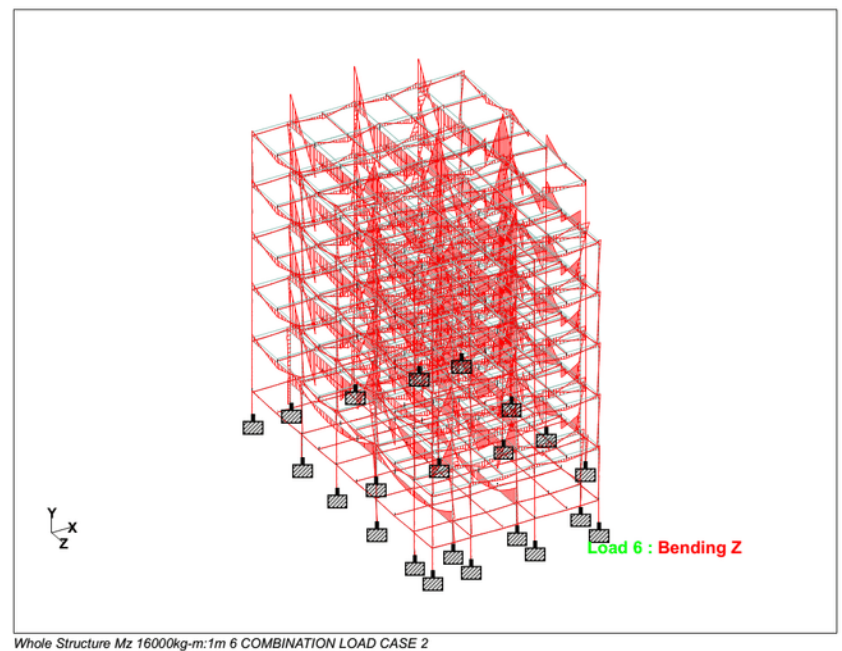

Gambar 7. Gambar momen portal gedung CSSD 5 lantai 
Pada lantai 4 untuk balok ukuran 45/90 didapat $\mathrm{Mu}^{+}=762,215 \mathrm{kNm}, \mathrm{Mu}^{-}=781,979$ $\mathrm{kNm}$ dan $\mathrm{Vu}=737,793 \mathrm{kN}$, balok ukuran 25/50 didapat $\mathrm{Mu}^{+}=115,925 \mathrm{kNm}, \mathrm{Mu}^{-}=$ $94,997 \mathrm{kNm}$ dan $\mathrm{Vu}=114,114 \mathrm{kN}$, balok ukuran $20 / 40$ didapat $\mathrm{Mu}^{+}=83,009 \mathrm{kNm}, \mathrm{Mu}^{-}=$ $77,548 \mathrm{kNm}$ dan $\mathrm{Vu}=137,653 \mathrm{kN}$ dan balok ukuran 20/30 didapat $\mathrm{Mu}^{+}=42,829 \mathrm{kNm}$, $\mathrm{Mu}^{-}=23,632 \mathrm{kNm}$ dan $\mathrm{Vu}=123,356 \mathrm{kN}$.

Pada lantai 5 untuk balok ukuran 45/90 didapat $\mathrm{Mu}^{+}=749,386 \mathrm{kNm}, \mathrm{Mu}^{-}=768,357$ $\mathrm{kNm}$ dan $\mathrm{Vu}=746,658 \mathrm{kN}$, balok ukuran 25/50 didapat $\mathrm{Mu}^{+}=114,897 \mathrm{kNm}, \mathrm{Mu}^{-}=$ $96,891 \mathrm{kNm}$ dan $\mathrm{Vu}=110.709 \mathrm{kN}$, balok ukuran $20 / 40$ didapat $\mathrm{Mu}^{+}=82,274 \mathrm{kNm}, \mathrm{Mu}^{-}=$ $77,273 \mathrm{kNm}$ dan $\mathrm{Vu}=137,534 \mathrm{kN}$ dan balok ukuran 20/30 didapat $\mathrm{Mu}^{+}=42,571 \mathrm{kNm}$, $\mathrm{Mu}^{-}=24,199 \mathrm{kNm}$ dan $\mathrm{Vu}=122,487 \mathrm{kN}$.

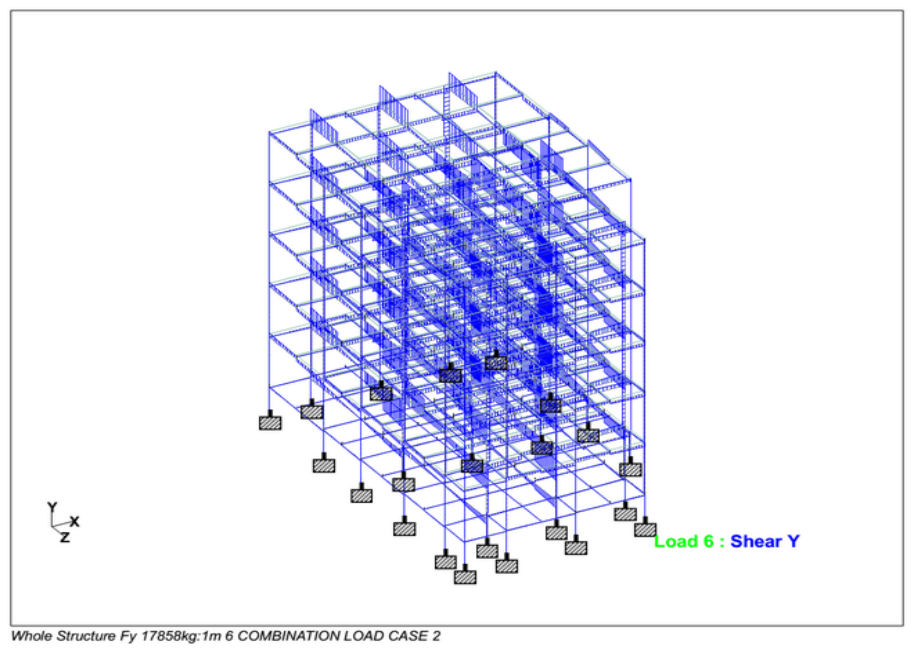

Gambar 8. Gambar shear Y portal gedung CSSD 5 lantai

Pada kolom untuk kolom ukuran 80/80 didapat $\mathrm{P}_{\mathrm{ud}}=233633 \mathrm{~kg}, \mathrm{M}_{\mathrm{ud}}=1.939 .335,7$ $\mathrm{kg}-\mathrm{cm}$ dan kolom ukuran 50/50 didapat $\mathrm{P}_{\mathrm{ud}}=147.155,34 \mathrm{~kg}, \mathrm{M}_{\mathrm{ud}}=468.171,9 \mathrm{~kg}-\mathrm{cm}$. Tinjauan terhadap beban arah $\mathrm{x}$ dengan gaya aksial yang ditahan oleh satu tiang bor sebesar $1.048,958 \mathrm{kN}$ dan arah y sebesar $1.064,752 \mathrm{kN}$.

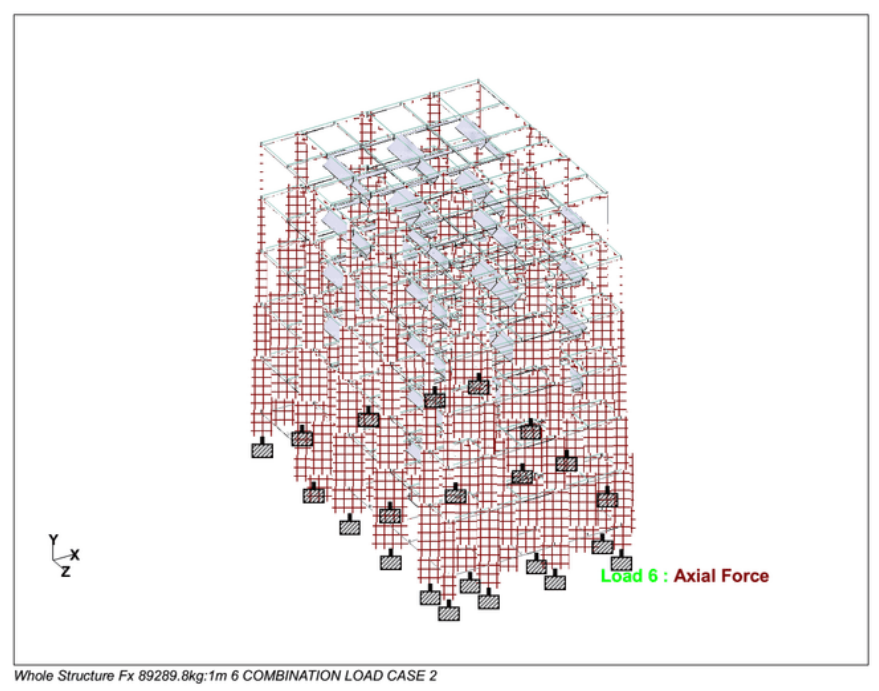

Gambar 9. Gambar axial force portal gedung CSSD 5 lantai 
Pada pekerjaan drainase, tanah dasar digali sesuai gambar kerja yang kemudian diurug kembali setelah dilakukan pemeriksaan pasangan batukali.

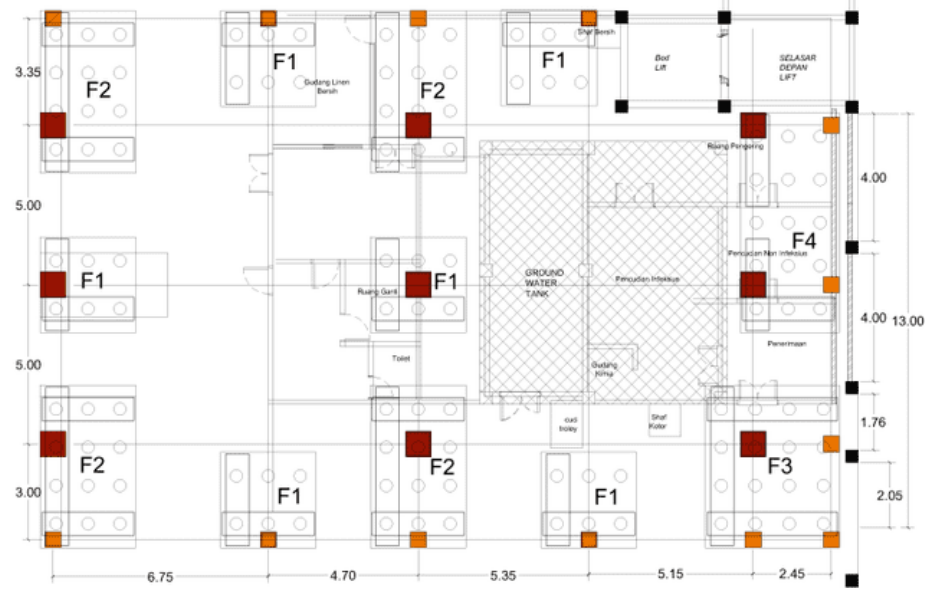

Gambar 10. Denah rencana pondasi gedung CSSD



Gambar 11. Detail pondasi gedung CSSD



Gambar 12. Denah balok gedung CSSD 


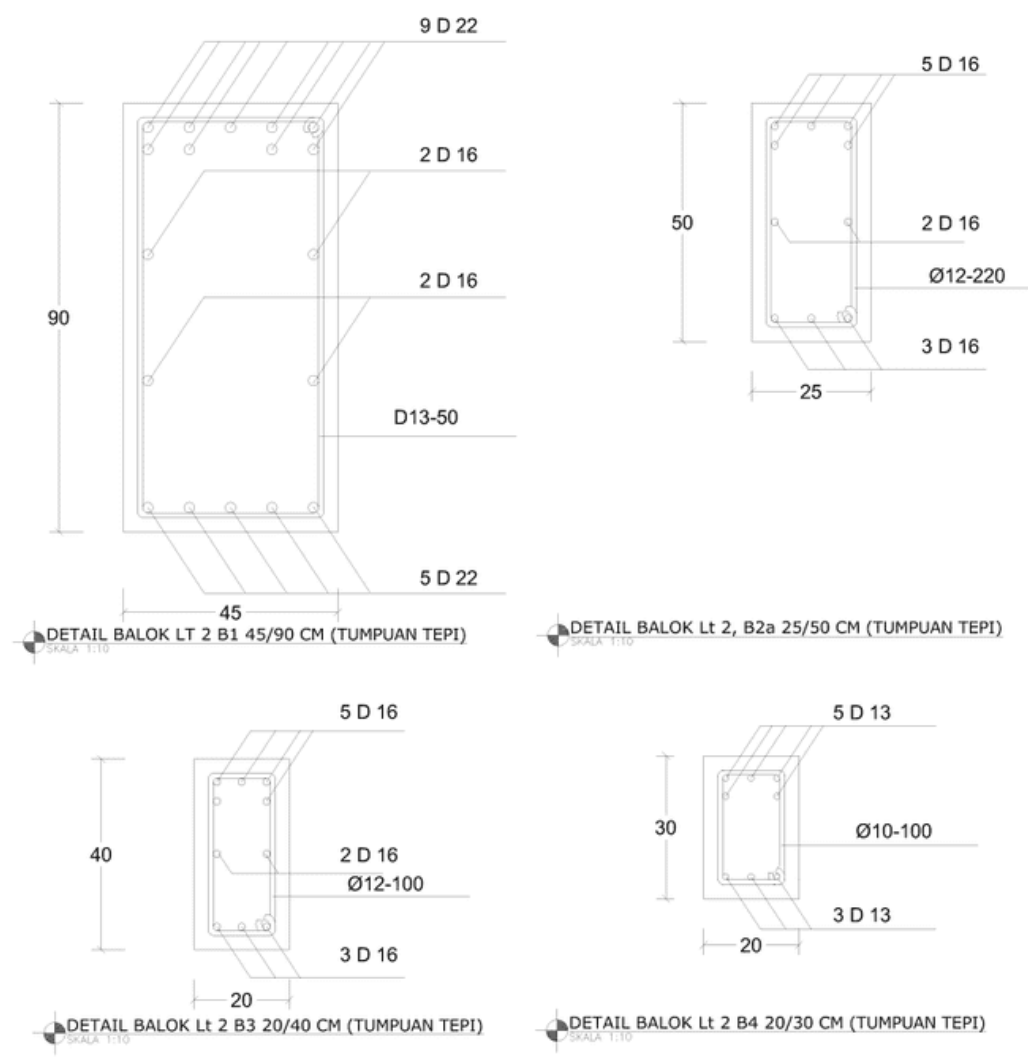

Gambar 13. Detail balok gedung CSSD

\section{ULASAN KARYA}

Penulis mendeskripsikan efektivitas dalam kegiatan perencanaan sutruktur ini adalah sebagai karya utama disesuaikan dengan kondisi lapangan. Kegiatan perencanaan struktur ini didukung oleh penggunaan software perhitungan struktur yaitu program STAAD Pro V8i sehingga hasil perhitungan ini lebih akurat dan cepat. Pelaksanaan kegiatan pengabdian masyarakat dengan rumah sakit Mawaddah Medika Mojokerto sebagai mitra merupakan aplikasi ilmu pengetahuan teknik sipil. Perencanaan konstruksi ditunjang dengan dukungan perangkat computer yang terinstal aplikasi STAAD Pro V8i serta tersedianya peralatan pendukung survei lapangan yang tersedia pada laboratorium struktur Universitas Tribhuwana Tunggadewi malang meningkatkan motivasi pihak rumah sakit, masyarakat Mojokerto serta pemerintah daerah Mojokerto untuk mendapatkan kualitas hasil perencanaan struktur yang baik. Kendala awal yang dihadapi pihak rumah sakit bisa terselesaikan dari kegiatan pendampingan ini karena tim penulis mempunyai kompetensi dalam perencanaan struktur yang ditunjang dengan kepemilikan settifikasi ahli bangunan gedung yang dimiliki oleh tim pelaksana kegiatan pengabdian masyarakat ini. Hasil dari sistem pendampingan mulai dari perhitungan pembebanan pada struktur, perhitungan momen, gaya aksial serta penentuan jumlah tulangan yang sesuai pada konstruksi beton tersebut. 


\section{DAMPAK DAN MANFAATKEGIATAN}

Dampak kegiatan ini antara lain terselesaikannya permasalahan mitra berupa terpenuhinya kebutuhan sumber daya manusia dengan keahlian struktur gedung. Terpenuhinya tahapan kegiatan perencanaan gedung mulai dari survei lahan, wawancara dengan pemilik dan masyarakat mengenai keamanan struktur gedung yang diinginkan. Dari hasil perencanaan struktur ini antara lain adalah tergambarkan momen serta gaya aksial yang harus dipikul oleh balok, kolom dan pondasi bangunan berdasarkan beban mati, beban hidup, beban air hujan serta beban gempa. Manfaat pelaksanaan kegiatan pengadian masyarakat dalam perencanaan struktur gedung 5 lantai ini adalah terhitungnya ukuran atau dimensi yang sesuai pada balok, kolom dan pondasi serta jumlah tulangan yang sesuai pada masing-masing balok, kolom dan pondasi berdasarkan momen dan gaya aksial yang dipikul oleh masing-masing balok, kolom dan pondasi. Dimensi dan jumlah tulangan pada balok, kolom dan pondasi dituangkan menjadi gambar kerja yang selanjutnya bisa untuk acuan dalam pelaksanaan pembangunannya. Dengan demikian maka mitra memiliki hasil perencanaan yang sesuai standard dan diaplikasikan dalam pelaksanaan pembangunannya

\section{KESIMPULAN}

Hasil kegiatan pengabdian masyarakat ini adalah terpenuhinya permasalahan mitra berupa kebutuhan perencanaan gedung yang sesuai standar dengan hasil perencanaan struktur yang memenuhi standar menjadikan bangunan rumah sakit ini memenuhi kaidah keamanan secara konstruksi sehingga pemanfaatan aktivitas di dalam struktur bangunan ini menjadi lebih maksimal. Dalam kegiatan pendampingan perencanaan struktur ini mendapat respon yang baik dari pihak rumah sakit Mawaddah Medika sertamasyarakat yang memanfaatkan pelayanan kesehatan pada rumah sakit tersebut. tercapainya target kegiatan adalah perencanaan struktur bangunan yang berkualitas serta efisien dari segi pembiayaan konstuksi. Hasil dari kegiatan perencanaan ini didapatkan dimensi sloof ukuran 40/70 cm, 20/40 cm dan 20/30 cm, sedangkan balok digunakan ukuran 45/90 cm, $25 / 50 \mathrm{~cm}, 20 / 40 \mathrm{~cm}$ dan 20/30 cm serta kolom ukuran 80/80 cm dan 50/50 cm. Sedangkan untuk pondasi digunakan tiang pancang dengan diameter $40 \mathrm{~cm}$ dengan kedalaman $6 \mathrm{~m}$. Efektifitas dalam penentuan jumlah tulangan pada masing-masing struktur beton berdasarkan momen yang dipikul oleh masing-masing batang. Hasil dari kegiatan pengabdian masyarakat ini, mitra memperoleh pendampingan perencanaan struktur bangunan gedung sehingga diperoleh implementasi perencanaan yang efektif dan efisien.

\section{DAFTAR PUSTAKA}

[1] K. A. R. Sakit, Standar Nasional Akreditasi Rumah Sakit edisi 1, 1st ed. Jakarta: Komisi Akreditasi Rumah Sakit, 2017.

[2] E. Kinyenje et al., "Status of Infection Prevention and Control in Tanzanian Primary Health Care Facilities: Learning From Star Rating Assessment," Infect. Prev. Pract., 
2020.

[3] B. Adu-Gyamfi, R. Shaw, and B. Ofosu, "Identifying exposures of health facilities to potential disasters in the Greater Accra Metropolitan Area of Ghana," Int. J. Disaster Risk Reduct., 2021.

[4] E. S. Mousavi, D. Bausman, and M. Tafazzoli, "Renovation in hospitals: Training construction crews to work in health care facilities," Am. J. Infect. Control, 2020.

[5] D. Tjitradi, E. Eliatun, and H. Afriono, "PERANCANGAN STRUKTUR BETON BERTULANG MENGGUNAKAN SOFTWARE STAADPRO V8i,” J. Kacapuri J. Keilmuan Tek. Sipil, 2021.

[6] L. Sharma, N. Taak, and P. K. Mishra, "A comparative study between the preengineered structures and conventional structures using STAADPRO," in Materials Today: Proceedings, 2021.

[7] A. Wahono, "Perencanaan Struktur Beton Bertulang Dengan Menggunakan Software SAP 90 dan Staad Pro Dalam Kajian Struktur Portal Dua Dimensi," J. Ilmu-Ilmu Tek., vol. 11, 2015.

[8] T. Subramani and D. Ponnuvel, "Seismic and Stability Analysis of Gravity Dams Using Staad PRO,” 2012.

[9] B. S. Nasional, "SNI 2847:2019 Tentang Persyaratan Beton Struktural Untuk Bangunan Gedung," Jakarta: Badan Standarisasi Nasional, 2019.

[10] B. S. Nasional, "SNI 1726:2019 Tentang Tata Cara Perencanaan Ketahanan Gempa Untuk Struktur Bangunan Gedung dan Non Gedung," Jakarta: Badan Standarisasi Nasional, 2019.

[11] Badan Standarisasi Nasional, "SNI 1727:2013 tentang Beban Minimum untuk Perencanaan Bangunan Gedung dan Struktur Lain," Jakarta: Badan Standarisasi Nasional, 2013. 